\title{
PENERAPAN MODEL PEMBELAJARAN OSBORN UNTUK MENINGKATKAN PRESTASI BELAJAR PESERTA DIDIK PADA POKOK BAHASAN LAJU REAKSI
}

\section{Fachri Reza Ramadhan*, Johni Azmi, Herdini Herdini}

Program Studi Pendidikan Kimia, Fakultas Keguruan dan Ilmu Pendidikan Universitas Riau, Kampus Binawidya KM 12,5, Pekanbaru 28293, Riau, Indonesia

\begin{tabular}{l}
\hline \multicolumn{1}{c}{ Informasi Artikel } \\
\hline Sejarah Artikel: \\
Diterima: 02-09-2020 \\
Disetujui : 23-01-2021 \\
Dipublikasikan: 27-01-2021 \\
\hline Keywords: \\
Osborn Learning Model, \\
Learning Achievement, \\
Rate of Reaction. \\
\hline
\end{tabular}

A b s trak

Penelitian ini bertujuan untuk mengetahui peningkatan prestasi belajar peserta didik terhadap penerapan model pembelajaran Osborn pada pokok bahasan Laju Reaksi. Penelitian ini dijalankan di kelas XI MIA SMA Muhammadiyah 1 Pekanbaru. Jenis penelitian ini adalah penelitian eksperimen dengan desain Randomized Control Group Pretest - Posttest Design. Sampel dari penelitian adalah peserta didik kelas XI MIA 3 sebagai kelas eksperimen dan peserta didik pada kelas XI MIA 4 sebagai kelas kontrol. Kelas eksperimen adalah kelas yang diterapkan model pembelajaran Osborn sedangkan kelas kontrol tidak diberi perlakuan. Teknik analisis data digunakan adalah uji-t. Berdasarkan hasil uji analisis data diperoleh $t_{\text {hitung }}>t_{\text {tabel }}$ yaitu $9,141>1,670$, artinya penerapan model pembelajaran Osborn dapat meningkatkan prestasi belajar peserta didik pada pokok bahasan Laju Reaksi di kelas XI MIA SMA Muhammadiyah 1 Pekanbaru.

\section{Ab s tract}

This research is aimed to determine the increase in student learning achievement toward the implementation of Osborn learning model on the subject of rate of reaction. This research was conducted at Muhammadiyah 1 Pekanbaru on class XI MIA SMA. The research is an experimental study with randomized control group pretest-posttest design. The sample of the study was students of class XI MIA 3 as an experimental class and students in class XI MIA 4 as a control class. The experimental class was applied to the Osborn learning model, while the control class was not treated. The data analysis technique used was the t-test. Based on the results of the data analysis test $t_{\text {count }}>t_{\text {table }}$ is $9,141>1.670$, meaning that the application of Osborn's learning model can improve student learning achievement on the subject of rate of reaction in class XI MIA SMA Muhammadiyah 1 Pekanbaru.

C 2021 JPK UNRI. All rights reserved

\footnotetext{
*Alamat korespondensi:

e-mail: fachrireza88@gmail.com

No. Telf: +628166456230
} 


\section{PENDAHULUAN}

Proses pembelajaran melibatkan proses interaksi antar peserta didik, antara peserta didik dan pendidik, serta antara peserta didik dan sumber belajar lainnya yang berlangsung secara edukatif pada suatu lingkungan belajar, sehingga peserta didik dapat membangun pengetahuan, sikap dan keterampilannya dalam mencapai tujuan pendidikan yang telah ditetapkan. Guru dalam proses pembelajaran berperan sebagai perancang, pengarah, pendidik, pembimbing, motivator, evaluator, dan fasilitator. Sehingga semua aktivitas Pembelajaran hendaknya diarahkan untuk membantu perkembangan dan kemampuan belajar peserta didik (Ridwan, 2014). Oleh karena itu, guru dituntut untuk dapat merancang suatu pembelajaran yang berlangsung secara efektif dengan merancang suatu stategi, media dan model pembelajaran yang tepat.

Bedsarkan analisis kebutuhan dan informasi yang didapat dari guru kimia kelas XI MIA di SMA Muhammadiyah 1 Pekanbaru, diketahui bahwa prestasi belajar peserta didik pada pokok bahasan laju reaksi masih belum memuaskan. Kenyataan tersebut didukung dengan nilai ulangan harian peserta didik pada pokok bahasan laju reaksi tahun ajaran 2018/2019, hanya sekitar 70\% peserta didik saja yang dapat mendapat nilai diatas rata-rata kriteria ketuntasan minimal (KKM). Nilai KKM yang ditetapakan sekolah untuk mata pelajaran kimia adalah 75 . Beberapa hal yang diduga menjadi penyebab banyaknya peserta didik yang belum mencapai nilai rata-rata kriteria ketuntasan minimal pada materi laju reaksi antara lain disebabkan karena peserta didik kurang tertarik akan pembelajaran dan kurang termotivasi untuk aktif belajar.

Guru selalu menerapkan metode diskusi kelompok dalam proses pembelajaran, yang tujuannya agar peserta didik dapat mengembangkan diri dalam menemukan sendiri pengetahuan baru terhadap konsep pelajaran yang akan dipelajari (Dwikoranto, 2011). Namun usaha guru masih belum cukup direspon dengan baik oleh peserta didik, sehingga menyebabkan peserta didik kurang mampu memahami dan memaknai konsep pada pembelajaran. Oleh sebab itu, materi yang dipelajari menghasilkan nilai ketuntasan belajar menjadi kurang memuaskan (Dwikoranto, 2011; Rosidi, 2015). Mengatasi permasalahan ini, upaya yang dapat dilakukan untuk membuat peserta didik dapat aktif berpartisipasi dalam proses pembelajaran. Maka diperlukan suatu model pembelajaran alternative yang berbentuk model pembelajaran Osborn.

Model pembelajaran Osborn merupakan suatu model pembelajaran dengan menggunakan metode atau teknik brainstorming. Dimana, teknik brainstorming digunakan untuk menghasilkan gagasan yang mencoba mengatasi segala hambatan dan kritik dimana peserta didik di dalam kelompoknya dapat bebas berpendapat menemukan solusi dari suatu permasalahan dengan mengumpulkan ide dari setiap anggota kelompoknya (Luthfiyati, 2013). Beberapa publikasi yang telah mengimplementasikan model pembelajaran Osborn dalam proses pembelajaran. Dianteri et al (2018) telah menerapkan model pembelajaran Osborn untuk meningkatkan hasil belajar siswa pada materi koloid. Penelitian yang lain juga mengembangkan model pembalajaran Osborn untuk meningkatkan kemampuan berpikir kriatif dan peracaya diri (Aziz et al 2015), untuk invesitagasi kemapuan berfikir kreatis matematis siswa (Pusposrini et al 2019), meningkat kemanpuan berfikir kreatif siswa yang diintegrasikan dengan model pembelajaran berbasis masalah dan diterapkan pada mata pelajaran matematika (Soeviatulfitri dan Kashardi, 2020), dan untuk meningkat kemampuan pemecahan masalah siswa (Nurafifah et al 2016).

Penelitian ini bertujuan untuk mengetahui peningkatan prestasi belajar peserta didik dengan penerapan model pembelajaran Osborn pada pokok bahasan Laju Reaksi di kelas XI SMA Muhammadiyah 1 Pekanbaru. 


\section{METODE PENELITIAN}

Penelitian dilaksanakan disalah satu SMA di Pekanbaru pada semester ganjil tahun ajaran 2019/2020 yaitu bulan Oktober - November 2019. Populasi dalam penelitian adalah peserta didik kelas XI MIA SMA Muhammadiyah 1 Pekanbaru. Sampel diambil berdasarkan hasil analisis uji normalitas dan uji homogenitas dari 4 kelas berdasarkan data nilai ulangan Termokimia. Pada uji normalitas dan uji homogenitas dieproleh bahwa kelas XI MIA 3 dan XI MIA 4 berdistribusi normal dan mempunyai kemampuan yang sama, maka kedua kelas tersebut dijadikan sebagai sampel. Diperoleh Kelas XI MIA 3 sebagai kelas eksperimen dan kelas XI MIA 4 sebagai kelas kontrol. Sintak model pembelajaran Osborn diringkaskan pada Tabel 1.

Tabel 1. Sintak dalam model pembelajaran osborn (Aziz, 2015)

\begin{tabular}{|c|c|}
\hline $\begin{array}{l}\text { Tahap Model } \\
\text { Pembelajaran }\end{array}$ & Kegiatan Pembelajaran \\
\hline Orientasi & $\begin{array}{l}\text { Kegiatan Awal } \\
\text { - Guru mengucapkan salam. } \\
\text { - Guru menunjuk salah satu peserta didik memimpin doa, } \\
\text { memeriksa kehadiran peserta didik, kebersihan dan kerapian } \\
\text { kelas. } \\
\text { - Peserta didik diminta duduk didalam kelompok yang terdiri } \\
\text { dari } 5 \text { orang yang telah ditentukan sebelumnya. } \\
\text { - Guru melakukan tanya-jawab kepada peserta didik tentang } \\
\text { materi sebelumnya. } \\
\text { - Guru memotivasi peserta didik dengan memberitahu suatu } \\
\text { - Germasalahan yang berkaitan dengan kehidupan sehari-hari. } \\
\text { Guru menyampaikan tujuan pembelajaran. }\end{array}$ \\
\hline Analisis & $\begin{array}{l}\text { Kegiatan Inti } \\
\text { - Guru membagikan lembar brainstorming kepada peserta didik } \\
\text { - Peserta didik melaksanankan tahap-tahap brainstorming yang } \\
\text { telah disimulasikan sebelumnya } \\
\text { - Peserta didik membaca lembar brainstorming yang telah } \\
\text { diberikan } \\
\text { - Guru menggambarkan kembali masalah yang telah disampaikan } \\
\text { diawal pembelajaran kepada peserta didik yang berkaitan } \\
\text { dengan materi kedalam lembar brainstorming (Mengamati) } \\
\text { - Peserta didik diberi kesempatan untuk mengajukan pertanyaan } \\
\text { mengenai hal yang belum dipahami (Menanya) }\end{array}$ \\
\hline Hipotesis & $\begin{array}{l}\text { - Peserta didik mengidentifikasi setiap masalah yang diberikan } \\
\text { dalam lembar brainstorming secara individu } \\
\text { - Guru mengawasi jalannya kegiatan pembelajaran dengan } \\
\text { melihat apakah peserta didik menganalisis secara individu atau } \\
\text { tidak }\end{array}$ \\
\hline Pengeraman & $\begin{array}{l}\text { - Peserta didik merumuskan penyelesaian yang berkaitan dengan } \\
\text { materi pada lembar brainstorming secara individu }\end{array}$ \\
\hline & $\begin{array}{l}\text { - Peserta didik bersama kelompoknya berdiskusi tentang } \\
\text { penyelesaian masalah berdasarkan pada gagasan pemecahan } \\
\text { masalah yang telah dibuat masing-masing individu dan gagasan } \\
\text { penyelesaian masalah yang paling tepat menurut kelompoknya } \\
\text { dituliskan dalam lembar brainstorming (Mengumpulkan Data). }\end{array}$ \\
\hline
\end{tabular}




\begin{tabular}{|c|c|}
\hline $\begin{array}{l}\text { Tahap Model } \\
\text { Pembelajaran }\end{array}$ & Kegiatan Pembelajaran \\
\hline Sintesis & $\begin{array}{l}\text { - Guru membagikan LKPD kepada peserta didik } \\
\text { - Peserta didik membuktikan gagasan dengan melakukan } \\
\text { percobaan yang ada di LKPD secara berkelompok } \\
\text { - Guru meminta peserta didik berdiskusi untuk memperluas } \\
\text { konsep dan mengolah data/informasi yang telah didapat dengan } \\
\text { mengerjakan LKPD, setiap anggota kelompok } \\
\text { bertanggungjawab atas terselesaikannya LKPD tersebut. } \\
\text { (Mengasosiasikan) }\end{array}$ \\
\hline \multirow[t]{3}{*}{ Verifikasi } & $\begin{array}{l}\text { - Peserta didik secara bergantian mempresentasikan hasil diskusi } \\
\text { kelompoknya didepan kelas (Mengkomunikasikan) } \\
\text { - Peserta didik dari kelompok lain menanggapi, mengoreksi atau } \\
\text { menambahkan yang disampikan temannya. }\end{array}$ \\
\hline & $\begin{array}{l}\text { - Guru memutuskan gagasan/ pendapat yang terbaik bersama } \\
\text { peserta didik }\end{array}$ \\
\hline & $\begin{array}{l}\text { Kegiatan Akhir } \\
\text { - Guru bersama-sama dengan peserta didik menyimpulkan secara } \\
\text { keseluruhan materi pelajaran yang telah dipelajari. } \\
\text { - Guru memberikan kesempatan kepada peserta didik untuk } \\
\text { menanyakan materi yang belum dipahami } \\
\text { - Guru memberikan soal evaluasi kepada peserta didik. } \\
\text { - Guru menugaskan peserta didik untuk membaca materi yang } \\
\text { akan dipelajari pada pertemuan selanjutnya. }\end{array}$ \\
\hline
\end{tabular}

Bentuk Penelitian adalah penelitian eksperimen dengan design pretest-posttest. Desain penelitian yang digunakan yaitu Design Randomized Control Group Pretest-Posttest. Desain penelitian ditunjukan pada Tabel 2.

Tabel 2. Desain penelitian

\begin{tabular}{lccc}
\hline \multicolumn{1}{c}{ Kelas } & Pretest & Perlakuan & Posttest \\
\hline Eksperimen & $\mathrm{T}_{0}$ & $\mathrm{X}$ & $\mathrm{T}_{1}$ \\
Kontrol & $\mathrm{T}_{0}$ & - & $\mathrm{T}_{1}$ \\
\hline
\end{tabular}

Teknik pengumpulan data dalam penelitian adalah teknik test prestasi belajar. Data yang dikumpulkan diperoleh dari: (1). Data hasil nilai ulangan Termokimia sebagai data awal yang digunakan untuk uji homogenitas. (2). Nilai pretest dan posttest pada kelas eksperimen dan kelas kontrol (pokok bahasan Laju Reaksi) yang digunakan untuk uji hipotesis. Sedangkan teknik analisis data yang digunakan pada penelitian adalah uji-t. pengujian statistik dengan uji-t dapat dilakukan berdasarkan kriteria data yang berdistribusi normal. Oleh sebab itu, sebelum dilakukan pengolahan data, terlebih dahulu dilakukan uji normalitas menggunakan uji Liliefors. Jika harga $\mathrm{L}_{\text {maks }}<\mathrm{L}_{\text {tabel }}$, maka data berdistribusi normal. Harga $L_{\text {tabel }}$ diperoleh dengan Persamaan 1 (Agus Irianto 2003):

$$
\mathrm{L}_{\text {tabel }}=\frac{0,886}{\sqrt{n}}
$$

Setelah data berdistribusi normal, kemudian dilakukan uji homogenitas dengan menguji varians kedua sampel (homogen atau tidak) terlebih dahulu dengan Persamaan 2: 


$$
\mathrm{F}=\frac{\text { Varians } \text { Terbesar }}{\text { Varians Terkecil }}
$$

Kemudian dilanjutkan dengan uji kesamaan rata-rata menggunakan uji-t dua pihak untuk mengetahui kehomogenan kemampuan kedua sampel dengan Persamaan 3:

$$
\mathrm{t}=\frac{\bar{x}_{1}-\bar{x}_{2}}{S_{g} \sqrt{\frac{1}{n_{1}}+\frac{1}{n_{2}}}}
$$

Standar deviasi gabungan $(\mathrm{Sg})$ dapat dihitung dengan menggunakan Persamaan 4 (Sudjana, 2016):

$$
S_{g}^{2}=\frac{\left(n_{1}-1\right) S_{1}{ }^{2}+\left(n_{2}-1\right) S_{2}{ }^{2}}{n_{1}+n_{2}-2}
$$

Persamaan uji-t pada uji homogenitas juga dapat digunakan untuk melihat perubahan hasil belajar berupa prestasi belajar peserta didik antara kelas eksperimen dan kelas kontrol. Uji-t yang digunakan dalam uji hipotesis adalah uji-t pihak kanan.

\section{HASIL}

\subsection{Hasil Analisis Data Awal}

Sebelum dilakukan uji homogenitas terlebih dahulu dilakukan uji normalitas data awal karena data yang digunakan untuk uji homogenitas dalam penelitian adalah data yang diperoleh dari nilai ulangan Termokimia yang telah terdistribusi normal. Hasil analisis uji normalitas dapat dilihat pada Tabel 3.

Tabel 3. Hasil analisis uji normalitas data awal

\begin{tabular}{ccccccc}
\hline Kelas & $\mathbf{N}$ & $\overline{\mathrm{X}}$ & $\mathbf{S}$ & $\mathbf{L}_{\text {maks }}$ & $\mathbf{L}_{\text {tabel }}$ & Keterangan \\
\hline XI MIA 2 & 31 & 77,80 & 6,31 & 0,205 & 0,159 & Tidak Berdistribusi \\
& & & & & & Normal \\
XI MIA 3 & 32 & 76,50 & 7,56 & 0,097 & 0,156 & Berdistribusi Normal \\
XI MIA 4 & 32 & 75,31 & 8,01 & 0,118 & 0,156 & Berdistribusi Normal \\
XI MIA 5 & 26 & 67,53 & 8,94 & 0,145 & 0,174 & Berdistribusi Normal \\
\hline
\end{tabular}

Dapat dilihat pada Tabel 3 diatas, bahwa dari empat kelas yang di uji normalitasnya terdapat tiga kelas yang berdistribusi normal, dimana harga $\mathrm{L}_{\text {maks }}<\mathrm{L}_{\text {tabel. }}$. Selanjutnya pasangan kelas yang memiliki selisih rata-rata yang paling dekat diuji kehomogenannya. Hasil pengolahan data uji homogenitas dapat dilihat pada Tabel 4.

Tabel 4. Hasil analisis uji homogenitas data awal

\begin{tabular}{ccccccccc}
\hline $\begin{array}{c}\text { Pasangan } \\
\text { Kelas }\end{array}$ & $\mathbf{N}$ & $\sum \mathbf{X}$ & $\overline{\mathbf{X}}$ & $\mathbf{F}_{\text {hitung }}$ & $\mathbf{F}_{\text {tabel }}$ & $\mathbf{t}_{\text {hitung }}$ & $\mathbf{t}_{\text {tabel }}$ & Ket. \\
\hline XI MIA 3 & 32 & 2448 & 76,50 & 1,12 & 1,84 & 0,61 & 1,67 & Homogen \\
XI MIA 4 & 32 & 2410 & 75,31 & & & & &
\end{tabular}

Berdasarkan Tabel 4 dapat dilihat bahwa kedua pasangan kelas merupakan pasangan kelas yang homogen. Sehingga Pasangan kelas yang homogen ini menyatakan bahwa pasangan kelas 
tersebut merupakan sampel penelitian. kemudian dilakukan pengundian dan didapatkan kelas XI MIA 3 sebagai kelas eksperimen dan kelas XI MIA 4 sebagai kelas kontrol.

\subsection{Uji Hipotesis}

Uji hipotesis dalam penelitian ini menggunakan data selisih nilai pretest dan posttest. Sebelum dilakukan uji hipotesis data selisish nilai pretest dan posttest dinormalkan terlebih dahulu. Hasil analisis dari data selisih nilai menggunakan uji normalitas dapat dilihat pada Tabel 5 dan hasil analisis pengolahan data pada uji hipotesis dapat dilihat pada Tabel 6 .

Tabel 5. Hasil analisis uji normalitas data selisih nilai pretest-posttest

\begin{tabular}{ccccccc}
\hline Kelas & $\mathbf{N}$ & $\overline{\mathbf{X}}$ & $\mathbf{S}$ & $\mathbf{L}_{\text {maks }}$ & $\mathbf{L}_{\text {tabel }}$ & Keterangan \\
\hline Eksperimen & 32 & 50,13 & 10,06 & 0,147 & 0,156 & \\
Kontrol & 32 & 18,25 & 16,97 & 0,147 & 0,156 & Berdistribusi Normal \\
\hline
\end{tabular}

Tabel 6. Hasil analisis uji hipotesis

\begin{tabular}{ccccccccc}
\hline Kelas & $\boldsymbol{N}$ & $\overline{\mathbf{X}}$ & $\sum \boldsymbol{X}$ & $\sum \mathbf{X}^{\mathbf{2}}$ & $\mathbf{S}_{\mathbf{g}}$ & $\mathbf{t}_{\text {hitung }}$ & $\mathbf{t}_{\text {tabel }}$ & keterangan \\
\hline Eksperimen & 32 & 60,13 & 1604 & 83536 & \multirow{2}{*}{13,95} & \multirow{2}{*}{9,141} & \multirow{2}{*}{1,670} & Hipotesis \\
Kontrol & 32 & 18,25 & 584 & 19584 & & & & diterima \\
\hline
\end{tabular}

Uji hipotesis yang didapat dari selisisih nilai pretest-postest dilakukan dengan menggunakan uji $\mathrm{t}$ pihak kanan, hasil uji hipotesis $\mathrm{t}_{\text {hitung }}=9,141$ dan nilai $\mathrm{t}_{\text {tabel }}$ pada $\alpha=0,05$ dengan $\mathrm{dk}=62$ adalah 1,670 artinya $t_{\text {hitung }}$ lebih besar daripada $t_{\text {tabel }}$ yaitu 9,141 > 1,670 sehingga hipotesis diterima, artinya peningkatan prestasi belajar peserta didik dengan penerapan model pembelelajaran Osborn dapat diterima.

\section{PEMBAHASAN}

Penelitian dilakukan di kelas XI MIA SMA Muhammadiyah 1 Pekanbaru untuk melihat peningkatan prestasi belajar peserta didik pada pokok bahasan Laju Reaksi dengan menerapkan model pembelajaran Osborn. Peningkatan prestasi belajar peserta didik di kelas XI MIA SMA Muhammadiyah 1 Pekanbaru dianalisis dengan uji hipotesis terhadap sampel penelitian, sebelum melakukan uji hipotesis terlebih dahulu dilakukan uji normalitas dan uji homogenitas sebagai syarat analisis.

Hasil dari uji normalitas pada data awal (dapat dilihat pada Tabel 2) menunjukkan bahwa dari seluruh anggota populasi yang diuji normalitasnya terdapat 3 kelas yang berdistribusi normal, karena diperoleh $\mathrm{L}_{\text {maks }} \leq \mathrm{L}_{\text {tabel. }}$. Pasangan kelas yang berdistribusi normal dan memiliki selisih nilai rata-rata yang paling dekat kemudian diuji homogenitasnya. Hasil perhitungan diperoleh bahwa pasang kelas XI MIA 3 dan XI MIA 4 memiliki kemampuan yang sama atau Homogen (dapat dilihat pada Tabel 3). Kemudian dilakukan pengundian dan diperoleh kelas XI MIA 3 sebagai kelas eksperimen dan XI MIA 4 sebagai kelas kontrol. Sebelum diberi perlakuan kedua kelas diberikan tes awal (pretest) yang bertujuan untuk mengetahui kemampuan dasar peserta didik. Selanjutnya diberikan perlakuan (pembelajaran) yang berbeda sesuai dengan RPP. Setelah seluruh kegiatan pembelajaran selesai dilakukan kedua kelas diberikan Posttest.

Selisih nilai posttest-pretest digunakan untuk uji hipotesis menggunakan uji-t pihak kanan. Hasil perhitungan dari uji hipotesis diperoleh nilai $t_{\text {hitung }}>t_{\text {tabel }}$ yaitu 9,141 $>1,670$ dengan $\mathrm{dk}=62$, maka hipotesis diterima. Hipotesis penelitian ini ialah "Penerapan Model Pembelajaran Osborn dapat 
Meningkatkan Prestasi Belajar Peserta Didik pada Pokok Bahasan Laju Reaksi di Kelas XI MIA SMA Muhammadiyah 1 Pekanbaru".

Peningkatan prestasi belajar peserta didik melalui penerapan model pembelajaran Osborn disebabkan karena setiap tahap model pembelajaran Osborn sangat berperan penting dalam meningkatkan kemampuan individu dan kelompok dalam pemecahan masalah sehingga peserta didik dapat berperan aktif dalam menemukan konsep-konsep belajar yang baru dan dapat membangun pengetahuannya sendiri, oleh karena itu pengetahuan yang diperoleh akan bertahan dalam waktu yang lama dan akan lebih bermakna.

Aktifitas peserta didik dalam proses pembelajaran dapat dilihat dalam setiap tahap pada model pembelajaran Osborn. Tahap pertama yaitu tahap orientasi yang merupakan tahap dimana peserta didik membaca suatu wacana yang disajikan pada lembar Brainstorming berupa permasalahan yang berhubungan dengan fenomena-fenomena yang sesuai dengan topik pembelajaran. Dengan membaca wacana peserta didik dapat membuka wawasanya terhadap permasalahan yang ingin dicari jawabannya. Adanya wacana merupakan cara untuk menciptakan situasi baru sehingga peserta didik menjadi termotivasi dalam proses pembelajaran dan dapat meningkatkan prestasi belajarnya, hal ini sesuai dengat pendapat Prayitno (1989) bahwa peserta didik yang memiliki motivasi belajar yang lebih tinggi akan lebih tekun, bersemangat, lebih tahan dan memiliki ambisi yang lebih tinggi dalam mencapai prestasi yang lebih baik dibandingkan dengan peserta didik yang kurang atau tidak memiliki motivasi belajar.

Tahap analisis merupakan tahap mengidentifikasi masalah secara mandiri, pada tahap ini peserta didik menggunakan teknik/metode brainstroming dimana peserta didik bebas mencurahkan pendapatnya atas permasalahan yang terdapat pada wacana yang telah dibaca. Pada tahap ini peserta didik (diarahkan) menuliskan identifikasinya berdasarkan wacana secara individu dengan menuliskan beberapa pertanyaan. Kegiatan ini membuat peserta didik terlatih dalam menyelidiki suatu fenomena dan mencari permasalahan yang ada sehingga peserta didik terlibat aktif dalam pembelajaran serta prestasi belajarnya dapat meningkat, hal ini sesuai dengan pendapat Zaini (2011) bahwa peserta didik yang aktif dalam belajar, pengetahuan yang diterima peserta didik akan lebih lama diingat sehingga hasil belajar menjadi lebih baik.

Tahap hipotesis berpusat pada permasalahan spesifik yang ditetapkan pada tahap analisis dan mengharuskan peserta didik untuk menghasilkan suatu gagasan/ide untuk memperoleh suatu jawaban (pemecahan masalah). Peserta didik pada tahap ini bekerja secara individu membuat suatu hipotesis dari rumusan masalah yang telah dibuatnya. Dengan adanya kegiatan ini peserta didik melatih kemampuannya dalam membangun pengetahuannya sendiri sehingga peserta didik dapat memperoleh pemahaman konsep dan pengetahuannya akan dapat diingat dalam waktu yang lama serta dapat membantu meningkatkan prestasi belajarnya. Hipotesis dari peserta didik pada dasarnya disusun berdasarkan pengetahuan yang telah dimilikinya dan dikaitkan dengan permasalahan yang telah dirumuskan, hal ini sesuai dengan pendapat Ratna (2011) bahwa faktor yang paling mempengaruhi belajar adalah pengetahuan awal peserta didik sehingga pelajaran yang baru dapat diadaptasi dengan pengetahuan yang telah dimiliki.

Tahap pengeraman merupakan tahap dimana peserta didik berdiskusi atau melakukan curah pendapat (brainstroming) bersama teman kelompoknya berdasarkan pada analisis masalah dan hipotesis yang telah dibuat oleh masing-masing individu. Sehingga menghasilkan jawaban yang paling benar menurut kelompoknya sesuai dengan topik permasalahan yang ada. Pada tahap pengeraman setiap individu terlibat aktif dalam mengemukakan pendapatnya sehingga materi pembelajaran akan lebih mudah dipahami dan dapat meningkatkan prestasi belajar, Hal ini sesuai dengan pendapat Suharsimi Arikunto (2002) bahwa adakalanya seorang peserta didik lebih mudah merima keterangan yang diberikan oleh teman sebangku atau teman yang lain karena tidak ada rasa enggan atau malu untuk bertanya. 
Tahap sintesis, pada tahap ini peserta didik melakukan diskusi kelas, setiap kelompok secara bergantian mempresentasikan hasil diskusi kelompoknya didepan kelas. Dari setiap gagasan yang diungkapkan oleh setiap kelompok, peserta didik diajak untuk berpikir, gagasan manakah yang terbaik. Tahap ini memunculkan berbagai macam gagasan yang berbeda-beda dari satu topik permasalahan. Hal ini dikarenakan keragaman dari cara berpikir masing-masing peserta didik untuk menyelesaikan suatu permasalahan. Dengan perbedaan inilah membuat peserta didik ingat dan paham sehingga di waktu yang akan datang peserta didik tidak akan melakukan kesalahan yang sama.

Tahap verifikasi, pada tahap ini guru menentukan gagasan terbaik dari berbagai gagasan yang masuk dari hasil diskusi setiap kelompok yang telah dipresentasikan di depan kelas. Kemudian gagasan yang dianggap sebagai jawaban yang paling benar diambil sebagai penyelesaian suatu masalah.

\section{KESIMPULAN DAN REKOMENDASI}

\subsection{Kesimpulan}

Berdasarkan hasil penelitian yang telah dilakukan dapat disimpulkan bahwa penerapan model pembelajaran Osborn dapat meningkatkan prestasi belajar peserta didik pada pokok bahasan laju reaksi di kelas XI MIA SMA Muhammadiyah 1 Pekanbaru.

\subsection{Rekomendasi}

Berdasarkan kesimpulan yang diperoleh, peneliti merekomendasikan kepada guru bidang studi kimia dapat menjadikan model pembelajaran Osborn sebagai salah satu alternatif model pembelajaran untuk meningkatkan prestasi belajar peserta didik khususnya pada pokok bahasan laju reaksi.

\section{DAFTAR PUSTAKA}

Agus Irianto. 2003. Statistika Konsep Dasar dan Aplikasinya. Kencana. Padang.

Aziz, M.A., Rochmad, dan Wijayanti, K. 2015. Kemampuan Berpikir Kreatif dan Self-Efficacy Siswa Kelas X SMK Teuku Umar Semarang dengan Model Pembelajaran Osborn. Unnes Journal of Mathematics Education. 4(3):230-237.

Aziz, M.A., Rochmad, Wijayanti. K., 2015. Kemampuan berpikir kreatif dan self-efficacy siswa kelas $\mathrm{X}$ SMK Teuku Umar semarang dengan model pembelajaran Osborn. Unnes Journal of Mathematics Education. 4(3): 230-237

Diantari, M., Hasan, M., Habibati. 2018. Penerapan model pembelajaran osborn untuk meningkatkan hasil belajar siswa pada materi koloid di kelas XI IPA 1 SMAN 1 Indrapuri. Jurnal Ilmiah Mahasiswa Jurusan Pendidikan kimia. 3(1): 22-31)

Dwikoranti, D. 2011. Aplikasi metode diskusi dalam mengembangkan kemampuan kognitif, afektif dan social dalam pembelajaran sains. Jurnal Penelitian Fisika dan Aplikasinya. (1)2: 40-49

Elida Prayitno. 1989. Motivasi Dalam Belajar dan Berprestasi. Departemen Pendidikan dan Kebudayaan Direktorat Jenderal Pendidikan Tinggi. Jakarta

Nurafifah, L., Nurlaelah, E., Usdiyana. D. 2016. Model pembelajaran osborn untuk meningkatkan kemampuan pemecahan masalah matematis siswa. Mathline; Jurnal Matematika dan Pendidikan Matematika. 1(2): 93-102

Pusporini, I.W., Abidin, Z., Fathani, A.H. 2019. Kemampuan berpikir kreatif matematis siswa melalui model pembelajaran osborn pada materi bangun datar segiempat kelas VII. JPPP.14(7): 130138

Ratna Wilis Dahar. 2011. Teori Belajar dan Pembelajaran. Erlangga. Jakarta.

Ridwan Abdullah Sani. 2014. Inovasi Pembelajaran. Bumi Aksara. Jakarta.

Rosidi, I. 2015. Pengembangan perangkat pembelajaran IPA terpadu tipe integrated untuk mengetahui ketuntasan belajar IPA siswa SMP pada topik pengelolaan lingkungan. Jurnal Pena Sains. 2(1): $14-15$

Soeviatulfitri, Kashardi. 2020. Kemampuan Berpikir Kreatif Matematis Siswa melalui Model Problem 
Based Learning (PBL) dan Model Pembelajaran Osborn di SMP. Jurnal Pendidikan Matematika Raflesia. 05(03); 35-43

Sudjana. 2016. Metoda Statistika. Tarsito. Bandung.

Suharsimi Arikunto. 2002. Pengelolaan Kelas dan Siswa. Rajawali. Jakarta.

Sukardi. 2007. Metodologi Penelitian Pendidikan Kompetensi dan Praktiknya. Bumi Aksara. Jakarta Zaini Hisyam. 2011. Strategi Pembelajaran Aktif. CTSD. Yogyakarta 